\title{
Effect of Customized Nutrient Mixture on Yield of Okra in Onattukara Sandy Plain
}

\author{
Mini V. *1, Usha Mathew ${ }^{2}$ \\ ${ }^{1}$ Agricultural Research Station, Kerala Agricultural University, Thiruvalla, India \\ ${ }^{2}$ College of Agriculture, Vellayani, Trivandrum, India
}

\begin{abstract}
A study was conducted in the Onattukara sandy plain (AEU 3) of Kerala to assess the available nutrient status of the region to develop a multi nutrient mixture for balanced crop nutrition and to evaluate the effect of multi nutrient mixture on growth and yield of okra. Two hundred georeferenced soil samples were drawn at random from twenty soil series of the Onattukara region and analysed for 13 soil fertility parameters. The soil was very strongly acidic with high level of phosphorus, low oxidisable organic carbon and available potassium and wide spread deficiencies of calcium, magnesium, boron and zinc. Micronutrient fertilizer requirement was computed based on the available micronutrient status of the region and crop requirement. A multi nutrient mixture having a composition of $\mathrm{Zn}(9.5 \%)+B(2.6 \%)+C u(1.2 \%)+M g(2.4 \%)+N$ (0.46\%)@20kg ha $\mathrm{k}^{-1}$ was developed and the effect of multi nutrient mixture was assessed in the field experiments using okra variety Varsha Uphar as the test crop. Application of soil test based NPK and secondary nutrients + foliar application of 0.5 per cent solution of computed dose of nutrient mixture@5 kg ha $\mathrm{k}^{-1}$ in two splits at 15 DAS and 30 DAS (T7) yielded significantly higher (11.3 $\left.\mathrm{t} \mathrm{ha}^{-1}\right)$ over rest of the treatments with a B: $C$ ratio of 3.02. Soil status of micronutrients in the experiment site before the experiment was $\mathrm{Zn}\left(0.27 \mathrm{mg} \mathrm{kg}^{-1}\right), \mathrm{Cu}\left(0.21 \mathrm{mg} \mathrm{kg}^{-1}\right)$ and $B(0.17 \mathrm{mg}$ $\left.\mathrm{kg}^{-1}\right)$. After two consecutive applications of multi nutrient mixture, the soil status of $\mathrm{Zn}, \mathrm{Cu}$ and $\mathrm{B}$ were in the range of 0.62 to $1.58 \mathrm{mg} \mathrm{kg}^{-1}, 0.74$ to $0.99 \mathrm{mg} \mathrm{kg}^{-1}$ and 0.19 to $0.31 \mathrm{mg} \mathrm{kg}^{-1}$ respectively. In general the highest nutrient content and uptake in shoot and fruit were recorded by $T 7$. Application of multi nutrient mixtures customized for agro ecological units and crops ensured increased yield and sustained soil health.
\end{abstract}

Keywords - Nutrient Mixture, Onattukara, sandy plain.

\section{INTRODUCTION}

Onattukara sandy plain is a fluvial and marine sand area of Alappuzha and Kollam districts of Kerala state in India, which covers an area of 40495 ha. Onattukara soil is coarse textured with low nutrient and water retention capacity. Now problems due to micronutrient deficiencies have been reported from many parts of this region (KSPB, 2013). The supplementation of micronutrients under such situation becomes more important to provide balanced nutrition to crops. Supplementation of micronutrients helps in correction of hidden hunger and better utilization of major nutrients resulting in better crop growth and yield (Mathew, 2007). $\mathrm{Zn}, \mathrm{Cu}$ and $\mathrm{B}$ deficiency are the most frequently observed micronutrient deficiencies in these soils. Micronutrient deficiencies causes remarkable losses in yield of vegetables and their deficiencies warrant the need for research on $\mathrm{Zn}, \mathrm{Cu}$ and $\mathrm{B}$, especially on their usage in mixtures as foliar/soil application. Hence the present investigation was undertaken to study the effect of different grades of multi nutrient mixtures on growth and yield of okra.

\section{MATERIALS AND METHODS}

Two hundred georeferenced soil samples were collected from twenty soil series of Onattukara region and analysed using standard analytical procedures (Jackson, 1973) to characterize the fertility status of the region. The soil was very strongly acidic with high level of phosphorus, low oxidisable organic carbon and available potassium and wide spread deficiencies of calcium, magnesium, boron and zinc. The soil analysis results revealed deficiency of B (77\%), Zn $(66 \%)$ and $\mathrm{Cu}(53 \%)$ in the region. To address the multiple micronutrient deficiencies, a multi micronutrient mixture is more economical than individual applications. Hence a multi nutrient mixture having a composition of $\mathrm{Zn}(9.5 \%)+$ $\mathrm{B}(2.6 \%)+\mathrm{Cu}(1.2 \%)+\mathrm{Mg}(2.4 \%)+\mathrm{N}(0.46 \%) @ 20 \mathrm{~kg} \mathrm{ha}^{-}$ 1 was developed based on the soil status and crop requirement of the test crop okra (cv. Varsha Uphar). Along with the deficient micronutrients, magnesium was added to ensure balanced nutrition and nitrogen was added to improve the efficiency of foliar absorption. Two field experiments were conducted in the Onattukara region during 2013-2014 for studying the effect of customized 
multi nutrient mixture in improving crop production of okra (cv. Varsha Uphar). The treatments consisted of T1 (Absolute control), T2 (Package of Practices (KAU,2011), T3 (Soil test based POP and secondary nutrients), T4 (Treatment $3+$ computed dose of nutrient mixture), T5 (Treatment $3+25 \%$ less of computed dose of nutrient mixture), T6 (Treatment $3+25 \%$ more of computed dose of nutrient mixture), $\mathrm{T} 7$ (Treatment $3+$ foliar application of $0.5 \%$ solution of computed dose of nutrient mixture), T8 (Treatment $3+$ foliar application of $0.5 \%$ solution of $25 \%$ less of computed dose of nutrient mixture) and T9 (Treatment $3+$ foliar application of $0.5 \%$ solution of $25 \%$ more of computed dose of nutrient mixture). Mode of application for T4, T5 and T6 was soil application @ $20 \mathrm{~kg}$ $\mathrm{ha}^{-1}$ and T7, T8 and T9 was $0.5 \%$ foliar spray application at 15 DAS and 30 DAS. The treatments were replicated thrice in randomized block design. The soil of the experimental field was Typic Ustipsamments and the initial physico chemical properties of the experimental site are given in Table 1.
Table.1: Physico- chemical properties of soil at experiment site

\begin{tabular}{|l|l|}
\hline Parameter & Value \\
\hline $\mathrm{pH}(1: 2.5)$ & 4.99 \\
\hline $\mathrm{EC}\left(\mathrm{d} \mathrm{S} \mathrm{m}^{-1}\right)$ & 0.04 \\
\hline Texture & Loamy sand \\
\hline Bulk density & $1.58 \mathrm{Mg} \mathrm{m}$ \\
\hline Particle density & $2.43 \mathrm{Mg} \mathrm{m}^{-3}$ \\
\hline Organic carbon \% & 0.58 \\
\hline Available nitrogen $\left(\mathrm{kg} \mathrm{ha}^{-1}\right)$ & 138.2 \\
\hline Available phosphorus $\left(\mathrm{kg} \mathrm{ha}^{-1}\right)$ & 29.92 \\
\hline Available potassium $\left(\mathrm{kg} \mathrm{ha}^{-1}\right)$ & 104.5 \\
\hline Available calcium $\left(\mathrm{mg} \mathrm{kg}^{-1}\right)$ & 209.15 \\
\hline Available magnesium $\left(\mathrm{mg} \mathrm{kg}^{-1}\right)$ & 48.16 \\
\hline Available sulphur $\left(\mathrm{mg} \mathrm{kg}^{-1}\right)$ & 5.07 \\
\hline Available iron $\left(\mathrm{mg} \mathrm{kg}^{-1}\right)$ & 12.05 \\
\hline Available manganese $\left(\mathrm{mg} \mathrm{kg}^{-1}\right)$ & 7.62 \\
\hline Available zinc $\left(\mathrm{mg} \mathrm{kg}^{-1}\right)$ & 0.27 \\
\hline Available copper $\left(\mathrm{mg} \mathrm{kg}^{-1}\right)$ & 0.21 \\
\hline Available boron $\left(\mathrm{mg} \mathrm{kg}^{-1}\right)$ & 0.17 \\
\hline
\end{tabular}

\section{RESULTS AND DISCUSSION}

\section{Growth and Yield}

Data on growth, yield and quality of okra Var. Varsha Uphar raised in the farmer's field of Onattukara region in the first and second season are presented in Tables 2 and 3.

Table.2: Effect of multi nutrient mixture on growth and yield

\begin{tabular}{|c|c|c|c|c|c|}
\hline \multirow{2}{*}{ Treatments } & \multicolumn{2}{|c|}{ Plant height(cm) } & \multicolumn{3}{c|}{ Yield (t ha $^{-\mathbf{1}}$ ) } \\
\cline { 2 - 6 } & Crop I & Crop II & Crop I & Crop II & $\begin{array}{c}\text { Pooled } \\
\text { Mean }\end{array}$ \\
\hline T1 & 68.5 & 70.2 & 2.29 & 2.17 & 2.23 \\
\hline T2 & 97.4 & 99.1 & 4.76 & 5.47 & 5.12 \\
\hline T3 & 109.8 & 111.4 & 6.00 & 6.57 & 6.29 \\
\hline T4 & 135.7 & 137.3 & 9.32 & 9.82 & 9.57 \\
\hline T5 & 117.7 & 119.3 & 7.34 & 8.10 & 7.72 \\
\hline T6 & 138.6 & 140.3 & 9.72 & 10.16 & 9.94 \\
\hline T7 & 142.7 & 144.3 & 11.08 & 11.52 & 11.30 \\
\hline T8 & 122.8 & 124.4 & 8.06 & 8.67 & 8.36 \\
\hline T9 & 117.8 & 119.3 & 7.40 & 8.24 & 7.82 \\
\hline CD(0.05) & $\mathbf{0 . 9 6}$ & $\mathbf{1 . 9 1 3}$ & $\mathbf{1 . 1 2 8}$ & $\mathbf{0 . 6 9 2}$ & $\mathbf{0 . 5 9 2}$ \\
\hline
\end{tabular}

Table.3: Effect of multi nutrient mixture on fruit quality

\begin{tabular}{|c|c|c|c|c|c|}
\hline \multirow[t]{2}{*}{ Treatments } & \multicolumn{2}{|c|}{ Protein (\%) } & \multicolumn{2}{|c|}{ Keeping quality (days) } & \multirow[t]{2}{*}{ B: C ratio } \\
\hline & Crop I & Crop II & Crop I & Crop II & \\
\hline T1 & 1.00 & 0.98 & 5.33 & 5.33 & 1.08 \\
\hline
\end{tabular}




\begin{tabular}{|l|l|l|l|l|l|}
\hline T2 & 1.10 & 1.13 & 7.33 & 7.33 & 1.56 \\
\hline T3 & 1.07 & 1.26 & 7.33 & 7.00 & 1.87 \\
\hline T4 & 1.53 & 1.51 & 8.33 & 8.33 & 2.68 \\
\hline T5 & 1.19 & 1.16 & 8.33 & 8.00 & 2.22 \\
\hline T6 & 1.56 & 1.54 & 9.00 & 9.00 & 2.70 \\
\hline T7 & 1.63 & 1.63 & 9.00 & 9.00 & 3.02 \\
\hline T8 & 1.38 & 1.35 & 9.00 & 8.67 & 2.25 \\
\hline T9 & 1.19 & 1.26 & 9.00 & 9.00 & 2.08 \\
\hline CD (0.05) & $\mathbf{0 . 2 2 5}$ & $\mathbf{0 . 2 7 8}$ & $\mathbf{0 . 5 2 7}$ & $\mathbf{0 . 6 6 6}$ & 0.166 \\
\hline
\end{tabular}

Growth, yield and quality of okra increased significantly due to multi nutrient mixture. Yield of okra in the soil test based NPK fertilizers and secondary nutrients alone(T3) ranged from 6.0 to $6.57 \mathrm{t} \mathrm{ha}^{-1}$ and in the treatments of soil test based NPK fertilizers and secondary nutrients+ $0.5 \%$ foliar application of multi nutrient mixture @ $5 \mathrm{~kg} \mathrm{ha}^{-1}(\mathrm{~T} 7)$, yield ranged from 11.08 to $11.52 \mathrm{t} \mathrm{ha}^{-1}$ in two seasons. Also, treatment $\mathrm{T} 7$ recorded 80 per cent more yield than $\mathrm{T} 3$, which was the soil test based package of practices (POP) and secondary nutrients. Soil application of this mixture @ $20 \mathrm{~kg} \mathrm{ha}^{-1}$ (T4) was also significantly superior to the POP recommendations. The hidden deficiencies of micronutrients were overcome due to their supplementation during the growth period, which resulted in better crop growth and thereby yield. The inherent status of secondary and micronutrients in the experimental site was very low as presented in Table 1. Hence balanced application of secondary and micronutrients through the multi nutrient mixture had a beneficial effect on plant growth and yield. In severe deficiency condition, the yield increase could reach over 100 per cent due to balanced use of fertilizers of major and micronutrients (Malakouti, 2007). Hazara et al. (1987) also reported that the application of micronutrient mixture was found beneficial in increasing okra yield due to increase in number of flowers, number of inflorescence/plant, number of fruits per plant and fruit size of okra as a result of application of boron and copper. All the treatments involving the application of multinutrient mixture recorded higher $\mathrm{B}$ : $\mathrm{C}$ ratio compared to those treatments without the mixture. The highest benefit: cost ratio of 3.02 was obtained due to the foliar application of computed dose of nutrient mixture (T7). These findings are in conformity with the observations of Singh and Verma (1991), who obtained maximum cost benefit ratio with foliar application of mixture of micronutrients.

\section{Soil status}

Soil status of micronutrients in the experimental site before conducting the experiment was $\mathrm{Zn}\left(0.27 \mathrm{mg} \mathrm{kg}^{-1}\right), \mathrm{Cu}(0.21$ $\left.\mathrm{mg} \mathrm{kg}^{-1}\right)$ and $\mathrm{B}\left(0.17 \mathrm{mg} \mathrm{kg}^{-1}\right)$. After two consecutive applications of multi nutrient mixture, the soil status of $\mathrm{Zn}$, $\mathrm{Cu}$ and $\mathrm{B}$ were in the range of 0.62 to $1.58 \mathrm{mg} \mathrm{kg}^{-1}, 0.74$ to $0.99 \mathrm{mg} \mathrm{kg}^{-1}$ and 0.19 to $0.31 \mathrm{mg} \mathrm{kg}^{-1}$ respectively (Table 4).

Table.4: Available $\mathrm{Zn}, \mathrm{Cu}$ and B in soil after the harvest of the second crop

\begin{tabular}{|l|l|l|l|}
\hline $\begin{array}{l}\text { Treatmen } \\
\text { ts }\end{array}$ & $\begin{array}{l}\mathrm{Zn}(\mathrm{mg} \\
\left.\mathrm{kg}^{-1}\right)\end{array}$ & $\begin{array}{l}\mathrm{Cu}\left(\mathrm{mg} \mathrm{kg}^{-}\right. \\
\left.{ }^{-}\right)\end{array}$ & $\begin{array}{l}\mathrm{B}(\mathrm{mg} \\
\left.\mathrm{kg}^{-1}\right)\end{array}$ \\
\hline T1 & 0.18 & 0.15 & 0.10 \\
\hline T2 & 0.31 & 0.25 & 0.17 \\
\hline T3 & 0.36 & 0.23 & 0.19 \\
\hline T4 & 1.51 & 0.88 & 0.30 \\
\hline T5 & 1.41 & 0.85 & 0.21 \\
\hline T6 & 1.58 & 0.95 & 0.31 \\
\hline T7 & 0.64 & 0.99 & 0.25 \\
\hline T8 & 0.63 & 0.74 & 0.20 \\
\hline T9 & 0.62 & 0.81 & 0.19 \\
\hline CD(0.05) & 0.095 & 0.160 & 0.041 \\
\hline
\end{tabular}

Even after continuous application of multi nutrient mixture for two seasons there was no toxicity of these micronutrients, but the soil status was improved. So application of multi micronutrient mixtures customized for agro ecological units and crops ensured increased yield and sustained soil health.

\section{Conclusion}

The study revealed that there is a scope for the use of mixture of multi micronutrients to overcome the multiple micronutrient deficiencies in Onattukara sandy plain. Foliar application of micronutrient mixture @ $5 \mathrm{~kg} \mathrm{ha}^{-1}$ in two splits at 15 DAS and 30 DAS was superior to soil application in respect of yield, quality and B: C ratio. Micronutrient deficiency is one of the yield barriers which can be broken down by including micronutrient fertilizers in the nutrient schedule of crops. 


\section{REFERENCES}

[1] Hazra, P., Maity, J. K. and Mandal, A. R. 1987. Effect of foliar application of micronutrients on growth and yield of okra. Prog. Hort. 19 (34) : 219-222 .

[2] Jackson, M. L. 1973. Soil Chemical Analysis ( $2^{\text {nd }}$ Ed.). Prentice Hall of India, New Delhi, 498 p.

[3] KAU (Kerala Agricultural University) 2011. Package of Practices Recommendations : Crops (14 ${ }^{\text {th }}$ Ed.), Directorate of Extension, Kerala Agricultural University, Thrissur, $360 \mathrm{p}$.

[4] KSPB (Kerala State PlanningBoard) 2013. Soil Fertility Assessment and Information for enhancing Crop Productivity in Kerala. Kerala State planning Board. Thiruvananthapuram $522 \mathrm{p}$.

[5] Malakouti, M. J. 2007. The effect of micronutrients in ensuring efficient use of macronutrientsTurk. J .Agric. $32: 215-220$.

[6] Mathew.U. 2007. Assessment of micronutrients in soils of Kerala. KSCSTE project report. 105 p.

[7] Singh, S. S and Verma, S. K. 1991. Influence of potassium, zinc and boron on growth and yield of tomato. Veg.Sci.18:122-129. 